\title{
PENGARUH KEPEMIMPINAN TRANSFORMASIONAL, DISIPLIN DAN MOTIVASI KERJA TERHADAP KINERJA GURU
}

\section{THE EFFECT OF TRANSFORMATIONAL LEADERSHIP, DISCIPLINE AND WORK MOTIVATION ON TEACHER PERFORMANCE}

\author{
Enriko Fermi ${ }^{1}$ \\ ${ }^{1}$ MTsN 5 Kota Padang \\ Jl. Raya Kuranji, Kecamatan Kuranji Kota Padang \\ Email: koika110414@gmail.com
}

Naskah Masuk: 29-04-2019

Naskah Diterima: 25-11-2018

Naskah Disetujui:7-12-2018

ABSTRACT

The study aims to determine how much Influence of Transformational Leadership, Discipline and Work Motivation on Teacher Performance MTsN 5 Padang. Study variables such as Transformational Leadership (X1), Discipline (X2), Work Motivation (X3) and Teacher Performance (Y) the data were collected by quisioner with 50 samples. The method of analysis used is multiple regression analysis. To test the hypothesis used t test and a significant $F$ with $0,00<0,05$ and Adjusted $R$ Square $\left(R^{2}\right) 83,2 \%$. The regression analysis showed that positive and significant influence of Transformational Leadership, Discipline and Work Motivation on Teacher Performance MTsN 5 Padang simultan cously or partially.

Keywords: Transformational Leadership, Work Discipline, Work Motivation, Teacher Performance

\begin{abstract}
ABSTRAK
Penelitian ini bertujuan untuk mengetahui seberapa besar pengaruh Kepemimpinan Transformasional, Disiplin dan Motivasi Kerja terhadap Kinerja Guru MTsN 5 Padang. Variabel penelitian yaitu Kepemimpinan Transformasional (X1), Disiplin (X2), Motivasi Kerja (X3) dan Kinerja Guru (Y) dengan pengumpulan data melalui kuesioner dengan sampel 50. Metode analisis data yang digunakan adalah analisis regresi berganda. Untuk uji hipotesis digunakan uji $t$ dan uji $F$ dengan signifikan 0,00 <0,05 dan Adjusted $R$ Square $\left(R^{2}\right)$ 83,2\%. Hasil analisis regresi menunjukkan adanya pengaruh yang signifikan antara Kepemimpinan Tranformasional, Disiplin dan Motivasi Kerja terhadap Kinerja Guru MTsN 5 Padang baik secara parsial maupun simultan.
\end{abstract}

Kata Kunci: kepemimpinan transformasional, disiplin kerja, motivasi kerja, kinerja guru

\section{PENDAHULUAN}

Sudarmanto (2009) mengatakan bahwa untuk mengetahui sejauh mana keberadaan peran dan kontribusi sumber daya manusia dalam mencapai keberhasilan organisasi, diperlukan pengukuran kinerja. Berdasarkan Permendiknas nomor 35 tahun 2010, kinerja guru adalah hasil penilaian terhadap proses dan hasil kerja yang dicapai dalam melaksanakan tugasnya. Kinerja guru dapat ditingkatkan apabila ada kesesuaian antara pekerjaan dengan keahliannya, begitu pula dengan penempatan guru pada bidang tugasnya (Suyati dan Suhari, 2014).

Kinerja guru dipengaruhi kondisi jiwanya dan jiwa mempengaruhinya dalam mengajar. Agar dapat mencapai 
taraf ideal dalam mengajar, maka para guru harus memiliki motivasi yang sangat tinggi dan kukuh dalam menggeluti profesinya sebagai tenaga pengajar. Memiliki tenaga pengajar ideal adalah harapan stakeholders pendidikan di tanah air. Namun persoalannya, bagaimana caranya para guru memiliki skuad yang ideal, paling tidak dengan menitikberatkan dimensi motivasinya dalam bekerja (Bungawati \& Syafaruddin, 2016).

Kepemimpinan adalah kemampuan untuk mempengaruhi suatu kelompok demi pencapaian tujuan (Robbins, 2008). Pemimpin harus mampu memberikan wawasan, membangkitkan kebanggaan, serta menumbuhkan sikap hormat dan kepercayaan dari bawahannya. Inti kesuksesan suatu organisasi pada dasarnya terletak pada pemimpinnya. Fungsi kepemimpinan dalam organisasi merupakan elemen yang sangat penting dalam pengelolaan sumber daya manusia. Selain memberikan pengarahan, juga memberikan motivasi dalam upaya peningkatan kinerja pegawai. Untuk mengembangkan kemajuan dan perkembangan kinerja pegawai, sangat tergantung kepada sumber daya manusia sebagai pengelola langsung. Oleh sebab itu kepemimpinan mempunyai peran besar dalam meningkatkan kinerja pegawai.

Sikap dan gaya serta perilaku kepemimpinan seorang pemimpin sangat besar pengaruhnya terhadap organisasi yang dipimpin bahkan sangat berpengaruh terhadap kinerja pegawai dalam organisasi tersebut. Mohamad (2012) dalam Sari (2013) menjelaskan bahwa kepemimpinan yang mempengaruhi suatu organisasi adalah kepemimpinan transformasional.

Kepemimpinan transformasional dapat mempengaruhi kinerja guru. Pemimpin yang efektif dalam menerapkan gaya tertentu dalam kepemimpinannya terlebih dahulu harus memahami siapa bawahan yang dipimpinnya, mengerti kekuatan dan kelemahan bawahannya dan mengerti bagaimana cara memanfaatkan kekuatan bawahan untuk mengimbangi kelemahan yang mereka miliki (Rani, 2009). Sebaliknya gaya kepemimpinan yang tidak disesuaikan dengan karakteristik guru dan tugas yang ada, dapat mendorong guru merasa kurang bersemangat dalam bekerja atau bahkan kehilangan semangat kerja, sehingga menyebabkan guru tidak bersungguhsungguh dalam bekerja dan perhatian 
yang tidak terpusat pada pekerjaan. Keadaan seperti ini berpengaruh terhadap hasil pekerjaan yang tidak optimal, juga terabaikannya kualitas dan kuantitas produksi. Tentu saja hal ini perlu mendapat perhatian khusus, karena dapat mengganggu kelancaran kegiatan perusahaan atau instansi.

Disiplin kerja juga merupakan variabel yang mempengaruhi kinerja guru. Untuk menjamin agar guru bekerja secara efektif dan efisien, maka perlu adanya peningkatan disiplin kerja guru. Kurangnya disiplin kerja guru dapat mengakibatkan berbagai hal yang negatif dalam hubungannya dengan pekerjaan guru (Bungawati \& Syafaruddin, 2016). Menurut Budi Setiyawan dan Waridin (2006), dan Aritonang (2005) disiplin kerja karyawan bagian dari faktor kinerja dan disiplin kerja memiliki pengaruh positif terhadap kinerja karyawan.

Motivasi kerja yang tinggi dalam sebuah organisasi sekolah akan berdampak positif yaitu tercapainya tujuan yang telah ditentukan oleh organisasi sekolah. Motivasi kerja dapat dioptimalkan dalam organisasi sekolah maka perlu diketahui faktor-faktor yang dapat mempengaruhi motivasi kerja itu. Faktor-faktor itu meliputi faktor internal yang bersumber dari dalam individu dan faktor eksternal yang bersumber dari luar individu. Faktor internal seperti sikap terhadap pekerjaan, bakat, minat, kepuasan, pengalaman, dan lain-lain serta faktor dari luar individu yang bersangkutan seperti pengawasan, gaji, lingkungan kerja dan kepemimpinan (Wahjosumidjo, 2001 dalam Bungawati \& Syafaruddin, 2016).

Setiap kegiatan yang dilakukan oleh seseorang didorong oleh suatu kekuasaan dalam diri orang tersebut, kekuatan pendorong inilah yang disebut motivasi. Motivasi kerja pegawai dalam suatu organisasi dapat dianggap sederhana dan dapat pula menjadi masalah yang kompleks karena pada dasarnya manusia mudah untuk dimotivasi dengan memberikan apa yang menjadi keinginannya. Masalah motivasi kerja dapat menjadi sulit dalam menentukan imbalan dimana apa yang dianggap penting bagi seseorang karena sesuatu yang penting bagi seseorang belum tentu penting bagi orang lain. Bila seseorang termotivasi ia akan berusaha berbuat sekuat tenaga untuk mewujudkan apa yang diinginkannya. Upaya yang keras belum tentu akan menghasilkan produktivitas seperti yang diharapkan, apabila tidak disalurkan 
pada arah yang dikehendaki organisasi.

Unsur kebutuhan berarti suatu keadaan internal yang menyebabkan hasil-hasil tertentu tampak menarik.

Menurut Luthans (2006) motivasi adalah proses sebagai langkah awal seseorang melakukan tindakan akibat kekurangan secara fisik dan psikis atau dengan kata lain adalah suatu dorongan yang ditunjukan untuk memenuhi tujuan tertentu. Apabila nilai ini tidak terjadi, maka akan terwakili oleh individuindividu yang mengeluarkan tingkat biaya tinggi yang sebenarnya berlawanan dengan kepentingan organisasi. Rendahnya kinerja dan motivasi pegawai yang dihadapi sebenarnya merupakan permasalahan klasik namun selalu update untuk didiskusikan. Motivasi dapat mempengaruhi dan dapat memberikan dorongan kepada seseorang untuk melakukan sesuatu. Faktor-faktor yang dapat meningkatkan motivasi kerja dapat bersifat individu seperti kebutuhan, sikap dan kemampuan, sedangkan yang bersifat organisasi meliputi pembayaran gaji, pengawasan, pujian dan pekerjaan itu sendiri (Farlens, 2011).

Menurut Hasibuan (2011) bahwa motivasi dapat meningkatkan produktivitas, kedisiplinan dan dapat mempertinggi rasa tanggung jawab karyawan terhadap tugas-tugasnya. Penelitian yang dilakukan oleh Listianto dan Setiaji (2007) menyatakan bahwa motivasi kerja berpengaruh positif dan signifikan terhadap kinerja karyawan. Selain itu juga penelitian yang dilakukan oleh Prasetyo dan Wahyuddin (2003) mendukung penelitian sebelumnya yang menyatakan bahwa motivasi berpengaruh positif dan signifikan terhadap kinerja karyawan dan dalam penelitian ini juga menyatakan motivasi merupakan faktor dominan yang mempengaruhi kinerja karyawan.

Sumber daya manusia merupakan tokoh sentral dalam sebuah instansi agar aktifitas manajemen berjalan dengan baik, MTsN 5 Padang harus memiliki guru yang berpengetahuan dan berketerampilan tinggi serta usaha untuk mengelola MTsN 5 Padang seoptimal mungkin sehingga kinerja guru meningkat. Kinerja yang baik adalah kinerja yang optimal yang sesuai dengan standar organisasi. Kinerja merupakan perbandingan hasil kerja yang dicapai oleh pegawai dengan standar yang telah ditentukan dengan SDM kepemimpinan yang baik terhadap 
bawahannya (Guritno \& Waridin, 2005).

Meningkatkan kinerja guru merupakan tantangan manajemen yang paling serius karena keberhasilan mencapai tujuan dan kelangsungan hidup MTsN 5 Padang tergantung pada kualitas kinerja sumber daya manusia yang ada di dalamnya. Kinerja guru yang tinggi sangatlah diharapkan, semakin banyak guru yang memiliki kinerja tinggi, maka produktivitas juga akan semakin meningkat.

Disiplin kerja sumber daya manusia yang baik ditentukan oleh kemampuan manajemen sumber daya manusia dalam organisasi serta pimpinan dari pegawai itu sendiri. Tingkat disiplin kerja guru sangat erat kaitannya dengan motivasi dan kepuasan kerja. Guru yang disiplin dalam bekerja akan dapat melakukan pekerjaan secara produktif.

Untuk meningkatkan kinerja guru, maka pimpinan harus berusaha memovitasikan gurunya agar dapat melaksanankan tugasnya dengan baik dan tepat waktu. Dalam konsep manajemen dijelaskan bahwa manusia harus digerakkan, dipimpin, dan harus mempunyai kesadaran yang tinggi untuk memanfaatkan tenaga dan kemampuannya agar memperolah hasil yang maksimal. Konsep ini menunjukkan gambaran produktivitas kerja yang tinggi, dimana kinerja merupakan suatu ukuran keberhasilan dan kemampuan pegawai dalam melaksanakan tugasnya.

Untuk mencapai tujuan organisasi, pimpinan dan guru-guru harus bekerja secara efektif dan efesien, sehingga kinerja dapat ditingkatkan. Dengan meningkatkan motivasi, baik secara material maupun motivasi secara spiritual, maka akan meningkatkan kinerja guru yang lebih baik. Semua faktor tersebut jika dimaksimalkan akan mampu mendukung kinerja.

Selain motivasi keberhasilan atau kinerja guru juga dipengaruhi oleh disiplin kerja dan kepemimpinan suatu organisasi. Demikian juga pimpinan pada MTsN 5 Padang, dalam kebijakannya dengan menggerakkan dan mengendalikan pegawainya perlu mendalami masalah-masalah yang berkaitan dengan kinerja guru. Kinerja dapat ditingkatkan melalui motivasi yang dilakukan oleh pimpinan MTsN 5 Padang.

Kinerja guru merupakan ukuran sejauh mana kemampuan guru untuk menjalankan tugasnya sesuai dengan 
yang diberikan instansi. Kepuasan kerja merupakan salah satu faktor yang sangat penting untuk mendapatkan kinerja yang optimal.

Penelitian ini bertujuan untuk mengetahui pengaruh kepemimpinan transformasional, disiplin dan motivasi kerja secara simultan dan parsial terhadap kinerja guru MTsN 5 Padang.

\section{METODOLOGI}

Desain penelitian ini adalah penelitian deskriptif. Penelitian deskriptif adalah mempelajari masalahmasalah dalam masyarakat, serta tata cara yang berlaku dalam masyarakat serta situasi-situasi tertentu, termasuk tentang hubungan kegiatan, sikap, pandangan serta proses yang sedang berlangsung dan pengaruh dari fenomena.

Penelitian ini menggunakan metode survey. Metode survey menurut Sugiyono (2011) adalah penelitian yang dilakukan pada populasi besar maupun kecil, tetapi data yang dipelajari adalah data dari sampel yang diambil dari populasi tersebut, sehingga dapat ditemukan kejadian-kejadian relatif, distributif dan hubungan antar variabel sosiologis maupun psikologis. Metode survey bertujuan untuk memperoleh fakta dan gejala yang ada dan mencari kelengkapan secara aktual tentang hubungan antar variabel satu dengan variabel lainnya yang diteliti. Diharapkan penelitian ini terarah pada kajian korelasi dan regresi antara variabel bebas dan variabel terikat.

Populasi dalam penelitian ini adalah semua guru di MTsN 5 Padang berjumlah 50 orang guru. Sampel dalam penelitian ini adalah semua jumlah populasi yaitu semua guru di MTsN 5 Padang sebanyak 50 orang dengan teknik pengambilan sampel adalah total population.

Teknik pengumpulan data yang digunakan dalam penelitian ini adalah dengan melakukan wawancara, observasi, membagikan kuesioner, dan studi literatur.

\section{HASIL DAN PEMBAHASAN}

Umur dalam keterkaitannya dengan perilaku individu di lokasi kerja yaitu di lingkungan sekolah MTsN 5 Padang biasanya adalah sebagai gambaran akan pengalaman dan tanggung jawab individu. Tabulasi umur responden dapat dilihat sebagai berikut:

Tabel 1. Umur Responden

\begin{tabular}{lrr}
\hline $\begin{array}{c}\text { Umur } \\
\text { (tahun) }\end{array}$ & $\begin{array}{c}\text { Jumlah } \\
\text { Responden }\end{array}$ & Persentase \\
\hline $31-40$ & 9 & $18 \%$ \\
$41-50$ & 32 & $64 \%$ \\
$51-60$ & 9 & $18 \%$ \\
Total & 50 & 100 \\
\hline Sumber: Data primer yang diolah, 2017
\end{tabular}


Berdasarkan tabel 1 dapat diketahui bahwa untuk umur responden terbanyak adalah antara 41-50 tahun yaitu 32 orang (64\%), sisanya antara usia 31-40 tahun dan antara 51-60 tahun masing-masingnya sebanyak 9 orang $(18 \%)$.

Jenis kelamin secara umum dapat memberikan perbedaan pada perilaku seseorang. Dalam suatu bidang kerja jenis kelamin sering menjadi pembeda aktivitas yang dilakukan oleh individu. Penyajian data berdasarkan jenis kelamin adalah sebagai berikut:

Tabel 2. Jenis Kelamin Responden

\begin{tabular}{lrr}
\hline Jenis Kelamin & $\begin{array}{c}\text { Jumlah } \\
\text { Responden }\end{array}$ & Persentase \\
\hline Laki-laki & 8 & 16 \\
Perempuan & 42 & 84 \\
Total & 50 & 100 \\
\hline Sumber: Data primer yang diolah, 2017
\end{tabular}

Berdasarkan tabel 2 dapat diketahui bahwa berdasarkan jenis kelamin, responden terbanyak adalah dengan jenis kelamin wanita sebanyak 42 orang $(84 \%)$ orang dan responden laki-laki ada sebanyak 8 (16\%) orang. Hal ini memberikan indikasi bahwa guru MTsN 5 Padang lebih banyak berjenis kelamin wanita dari pada lakilaki.

Pendidikan sering dipandang sebagai kondisi yang mencerminkan kemampuan seseorang. Penyajian data responden berdasarkan pendidikan adalam sebagai berikut:

Tabel 3. Pendidikan Responden

\begin{tabular}{lrr}
\hline \multicolumn{1}{c}{ Pendidikan } & $\begin{array}{c}\text { Jumlah } \\
\text { Responden }\end{array}$ & Persentase \\
\cline { 3 - 3 } S1 & 49 & 98 \\
S2 & 1 & 2 \\
Total & 50 & 100 \\
\hline \multicolumn{2}{l}{ Sumber: Data primer yang diolah, 2017}
\end{tabular}

Berdasarkan tabel 3 dapat diketahui bahwa berdasarkan pendidikan responden, pendidikan responden yang paling banyak yaitu pendidikan S1 sebanyak 49 orang (98\%) orang dan responden dengan pendidikan S2 ada sebanyak 1 (2\%) orang. Hal ini memberikan indikasi bahwa guru MTsN 5 Padang lebih banyak berpendidikan $\mathrm{S} 1$.

Model persamaan regresi yang baik adalah yang memenuhi persyaratan asumsi klasik, antara lain semua data berdistribusi normal, model harus bebas dari gejala multikolinieritas dan terbebas dari heterokedastisitas. Dari analisis sebelumnya telah terbukti bahwa model persamaan yang diajukan dalam penelitian ini telah memenuhi persyaratan asumsi klasik sehingga model persamaan dalam penelitian ini sudah dianggap baik. Analisis regresi digunakan untuk menguji hipotesis tentang pengaruh secara parsial variabel bebas terhadap variabel terikat. 
Berdasarkan estimasi regresi berganda diperoleh hasil seperti tabel berikut ini.

Tabel 4. Hasil Estimasi Regresi Coefficients* sebesar 0,406 satuan bobot dan dapat diasumsikan bahwa kepemimpinan transformasional dan motivasi konstan.

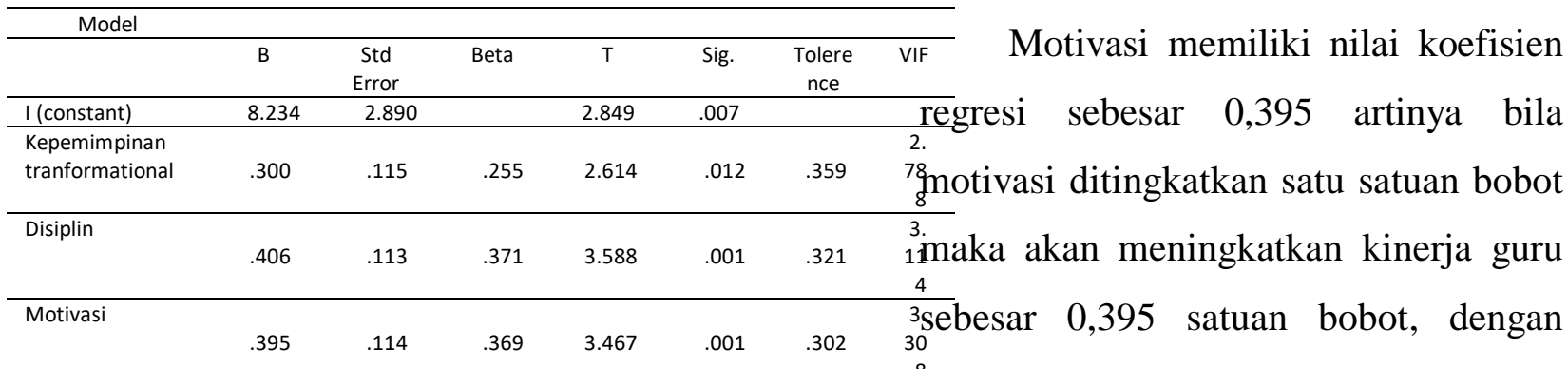

Berdasarkan tabel 4.13 di atas dapat diketahui persamaan regresi yang terbentuk adalah:

$Y=8,234+0,300 X 1+0,406 \mathrm{X} 2+0,395 \mathrm{X} 3$

Keterangan:

$\mathrm{Y}=$ Kinerja guru

$\mathrm{X} 1$ = Gaya Kepemimpinan

$\mathrm{X} 2=$ Disiplin

X3 = Motivasi kerja

Transformasional memiliki nilai koefisien regresi sebesar 0,300, artinya bila kepemimpinan transformasional ditingkatkan satu satuan bobot maka akan meningkatkan Kinerja Guru sebesar 0,300 satuan bobot, sebaliknya bila kepemimpinan transformasional menurun satu satuan bobot maka akan menurunkan kinerja pegawai sebesar 0,300 satuan bobot, dengan asumsi disiplin dan motivasi konstan.

Disiplin memiliki nilai koefisien regresi sebesar 0,406 artinya bila disiplin ditingkatkan satu satuan bobot maka akan meningkatkan kinerja guru asumsi kepemimpinan transformasional dan disiplin konstan.

Untuk menguji pengaruh variabel bebas secara bersama-sama diuji dengan menggunakan uji F. Hasil perhitungan regresi secara simultan diperoleh sebagai berikut:

Tabel 5. Hasil Analisis Regresi secara Simultan

\begin{tabular}{|c|c|c|c|c|c|}
\hline Model & $\begin{array}{l}\text { Sun of } \\
\text { Square }\end{array}$ & Df & $\begin{array}{l}\text { Mean } \\
\text { Square }\end{array}$ & $\mathrm{F}$ & Sig. \\
\hline $\begin{array}{r}1 \\
\text { Regression }\end{array}$ & 1023.553 & 3 & 341.184 & 81.987 & $.000^{\mathrm{b}}$ \\
\hline Residual & 191.427 & 46 & 4.161 & & \\
\hline Total & 1214.980 & 49 & & & \\
\hline
\end{tabular}

Pengujian pengaruh variabel bebas secara bersama-sama terhadap variabel terikatnya dilakukan dengan menggunakan uji F. Hasil perhitungan statistik menunjukkan nilai $\mathrm{F}$ hitung 81,987 dengan menggunakan batas signifikansi 0,05, maka diperoleh nilai signifikansi tersebut lebih kecil dari 0,05 . Hal ini berarti bahwa hipotesis yang menyatakan bahwa secara simultan variabel gaya kepemimpinan, 
disiplin dan motivasi kerja mempunyai pengaruh terhadap kinerja guru.

\section{Diskusi}

Hasil pengujian hipotesis (H1) telah membuktikan terdapat pengaruh gaya kepemimpinan transformasional terhadap kinerja guru. Melalui hasil perhitungan yang telah dilakukan diperoleh nilai t hitung sebesar 3,628 dengan signifikansi $(0,05)$. Secara statistik membuktikan bahwa gaya kepemimpinan berpengaruh positif terhadap kinerja guru. Artinya bahwa ada pengaruh antara variabel gaya kepemimpinan transformasional terhadap kinerja guru di MTsN 5 Padang. Hasil ini didukung oleh Suranta (2002) yang menjelaskan bahwa kepemimpinan transformasional mempunyai pengaruh positif dan signifikan terhadap kinerja guru.

Hasil pengujian hipotesis yaitu terdapat pengaruh antara motivasi terhadap kinerja guru dengan nilai $t$ hitung sebesar 3,628 dan signifikansi hasil sebesar $0,000 \quad(0,05)$. Secara statistik membuktikan bahwa motivasi berpengaruh positif terhadap kinerja guru. Artinya bahwa ada pengaruh antara variabel motivasi terhadap kinerja guru di MTsN 5 Padang. Hasil ini mendukung penelitian sebelumnya oleh Suharto dan Cahyono (2005) yang menyatakan bahwa ada pengaruh positif dan signifikan antara motivasi terhadap kinerja guru.

Hasil pengujian hipotesis (H3) telah membuktikan terdapat pengaruh antara disiplin terhadap kinerja guru dengan nilai t hitung sebesar 2,665 dan signifikansi hitung sebesar 0,009 $(0,05)$. Secara statistik membuktikan bahwa disiplin kerja berpengaruh positif terhadap kinerja guru. Artinya bahwa ada pengaruh antara variabel disiplin kerja terhadap kinerja guru di MTsN 5 Padang. Hasil ini mendukung penelitian sebelumnya oleh Setiyawan dan Waridin (2006) yaitu adanya pengaruh secara positif antara disiplin kerja terhadap kinerja guru.

\section{KESIMPULAN}

Hasil penelitian menunjukkan bahwa kepemimpinan transformasional, disiplin dan motivasi kerja secara signifikan dan berpengaruh positif terhadap kinerja guru yaitu sebesar $83.2 \%$ sedangkan $16.8 \%$ sisanya dipengaruhi variabel lain.

Hasil penelitian menunjukkan kepemimpinan transformasional, disiplin dan motivasi kerja secara bersama-sama berpengaruh positif terhadap kinerja guru. Dilihat dari 
perhitungan yang telah dilakukan diperoleh tingkat signifikan lebih kecil dari alpha $(0,000<0,005)$ dan nilai Koefisien Adjusted $\mathrm{R}^{2}$ adalah 83,2\%.

Kepemimpinan transformasional secara parsial berpengaruh positif terhadap kinerja guru. Dilihat dari perhitungan yang telah dilakukan tingkat signifikan lebih kecil dari alpha $(0,012<0,05)$ dan nilai koefisien regresi adalah sebesar 0,300 .

Disiplin secara parsial berpengaruh positif terhadap kinerja guru. Dilihat dari perhitungan yang telah dilakukan tingkat signifikan lebih kecil dari alpha $(0,001<0,05)$ dan nilai koefisien regresi adalah sebesar 0,406 .

Motivasi kerja secara parsial berpengaruh positif terhadap kinerja guru. Dilihat dari perhitungan yang telah dilakukan diperoleh tingkat signifikan lebih kecil dari alpha

\section{DAFTAR PUSTAKA}

Arif Rahman Hakim dan Yahya (2014), Analisis pengaruh gaya kepemimpinan, motivasi kerja, dan kompensasi terhadap kinerja guru (Studi Kasus Di SMA PPMI Assalam Surakarta) Alumni, Program Studi Pendidikan Akuntansi FKIP-UMS Dosen Program Studi Pendidikan Akuntansi FKIPUMS, Jurnal Pendidikan Ilmu Sosial, Vol. 24, No. 1, Juni 2014.

Aritonang, K. T. (2005). Kompensasi Kerja, Disiplin Kerja Guru dan Kinerja Guru SMP Kristen BPK Penabur. Jurnal
$(0,001<0,05)$ dan nilai koefisien regresi adalah sebesar 0,395 .

\section{REKOMENDASI}

Disarankan sekolah dalam meningkatkan kinerja guru lebih menitikberatkan pada motivasi guru, dilihat dari kuesioner yang telah diisi oleh guru MTsN 5 Padang diperoleh data bahwa karyawan memiliki motivasi yang tinggi pada pekerjaan yang mereka laksanakan, sehingga dengan sekolah lebih memotivasi guru misalnya dengan pemberian penghargaan terhadap guru yang berprestasi atau kenaikan pangkat akan dapat meningkatkan kinerja guru yang lebih baik lagi.

Bagi penelitian selanjutnya dapat menambah variabel lain yang dapat mempengaruhi kinerja guru karena dengan semakin baik kinerja dari guru maka akan berpengaruh baik juga bagi sekolah.

Pendidikan Penabur. No. 4. Th IV. Jakarta.

Bafadal, Ibrahim. (2009). Manajemen Peningkatan Mutu Sekolah Dasar: Dari Sentralisasi Menuju Desentralisasi. Indonesia. Jakarta: Bumi Aksara.

Bangun, Wilson. (2012). Manajemen Sumber Daya Manusia. Jakarta: Erlangga.

Budi, Setiyawan dan Waridin. (2006). Pengaruh Disiplin Kerja Karyawan dan Budaya Organisasi terhadap Kinerja di Divisi Radiologi RSUP Dokter Kariadi, Semarang: JRBI. Vol 2. No 2. Hal: 181-198. 
Bungawati \& Syafaruddin. (2016). Pengaruh Kepemimpinan , Motivasi Kerja , dan Disiplin Kerja terhadap Kinerja Guru SMKN 7 Makassar, $10(\mathrm{c}), 1-15$.

Danang, S \& Burhanudin. (2011). Perilaku Organisasi. Seturan Utara, Sleman, Yogyakarta: CAPS.

Darmawan. (2013). Metode Penelitian Kuantitatif. Bandung: Remaja Rosdakarya.

Farlen, Frans. (2011). Pengaruh Motivasi Kerja dan Kemampuan Kerja terhadap Kinerja Karyawan (Studi pada karyawan PT. United Tractors, Tbk Samarinda). Skripsi. Yogyakarta: Universitas Pembangunan Nasional Veteran.

Guritno, B. \& Waridin. (2005). Pengaruh Persepsi Karyawan Mengenai Perilaku Kepemimpinan, Kepuasan Kerja dan Motivasi terhadap Kinerja. JRBI. Vol 1. No 1. Hal: 63-74.

Hakim, Abdul. (2006). Analisis Pengaruh Motivasi, Komitmen Organisasi dan Iklim Organisasi terhadap Kinerja Pegawai pada Dinas Perhubungan dan Telekomunikasi Provinsi Jawa Tengah. JRBI. Vol 2. No 2. Hal: 165-180.

Handoko. (2010). Manajemen Personalia \& Sumber Daya Manusia, Edisi kedua. Yogyakarta: BPFE UGM.

Hasibuan, Malayu S.P. (2010). Organisasi dan Motivasi Dasar Peningkatan Produktivitas. Cetakan Ketujuh. Jakarta: PT. Bumi Aksara.

Hersey, P \& Blanchard, K. (2011). Manajemen Perilaku Organisasi: Pendayagunaan Sumber Daya Manusia. Jakarta: Erlangga.

Kadarisman, M. (2012). Manajemen Kompensas. Jakarta: Rajawali Pers.

Kuncoro, Mudrajad (2006), Strategi: Bagaimana Meraih Keunggulan Kompetitif. Jakarta: Erlangga.

Listianto, Tony \& Setiaji, Bambang. (2005). Pengaruh Motivasi, Kepuasan, dan Disiplin Kerja terhadap Kinerja Karyawan (Studi Kasus di Lingkungan
Pegawai Kantor PDAM Kota Surakarta).

Luthans, Fred. (2006). Perilaku Organisasi, Edisi Sepuluh. Yogyakarta: Andi Yogyakarta.

Mangkunegara, A. P. (2013). Manajemen Sumber Daya Manusia Perusahaan. Bandung: Remaja Rosdakarya.

Masngudi. (2003). Metodologi Penelitian untuk Ekonomi Edisi Kelima. Jakarta: Badan Penerbit Fekon Universitas

Borobudur.Mathis, R \& Jackson, J. (2011). Human Resource Management (edisi 10). Jakarta: Salemba Empat.

Notoadmodjo, Soekidjo. (2009). Pengembangan Sumber Daya Manusia. Jakarta: Rineka Cipta.

Nitisemito, A. (2010). Manajemen personalia Manajemen Sumber Daya Manusia. Ketiga. Jakarta : Ghalia Indonesia.

Paarlberg, L.E., dan Lavigna, B., (2010). Transformational Leadership and Public Service Motivation: Driving Individual and Organizational Performance. Public Administration Review, September/October, 710-718.

Prasetyo, E \& Wahyuddin. (2003). Pengaruh Motivasi dan Kepuasan Kerja terhadap Produktivitas Kerja Karyawan Riyadi Palace Hotel di Surakarta. Tesis Program Pascasarjana Universitas Muhammadiyah Surakarta. Solo.

Rahmawati, C. W. (2010). Pengaruh SDM dan Pemanfaatan Teknologi Informasi Terhadap Keterandalan dan ketepatwaktuan Pelaporan Keuangan Pemerintah daerah dengan variabel intervening pengendalian intern akuntans, studi empiris, di pemda subosukawonoseraten, Simposium Nasional Akuntansi XII Purwakarta.

Rani, Mariam. (2009). Pengaruh Gaya Kepemimpinan dan Budaya Organisasi terhadap Kinerja Karyawan Melalui Kepuasan Kerja Karyawan sebagai Variabel Intervening Studi Pada Kantor Pusat PT.Asuransi Jasa Indonesia 
(Persero), Tesis, Universitas Diponegoro Semarang.

Reza, R. A. (2010). Pengaruh Gaya Kepemimpinan, Motivasi, dan Disiplin Kerja terhadap Kinerja Karyawan PT. Sinar Sentosa Perkasa: Banjarnegara.

Rivai, V \& Jauvani, S. (2010). Manajemen Sumber Daya Manusia untuk Perusahaan dari Teori ke Praktik. Jakarta: PT Raja Grafindo.

Robbins \& Timothy, A. J. (2008). Perilaku Organisasi. Jakarta: Salemba Empat.

Sardiman. A. M. (2010). Interaksi dan Motivasi Belajar Mengajar. Jakarta: Rajawali Pers.

Sari, S. (2014). Pengaruh Gaya Kepemimpinan Transformasional Manajer terhadap Kreativitas Kerja Pegawai pada Divisi Pengembangan Sumber Daya Manusia. Bandung: PT.Dirgantara Indonesia.

Sadeghi dan Pihie. (2012). Transformational Leadership and Its Predictive Effects on Leadership Effectiveness. Jurnal Internasional.

Siagian, P. S. (2012). Teori Motivasi dan Aplikasinya. Jakarta: Rineka Cipta.

Singodimedjo. (2002). Menejemen Sumber Daya Manusia. Jakarta: Bumi Aksara.

Siswanto. (2010). Pengantar Manajemen. Jakarta: PT. Bumi Aksara.
Stoner, F .(1996). Manajemen Jilid II. Jakarta: Erlangga.

Sudarmanto. (2009). Kinerja dan Pengembangan Kompetensi SDM. Yogyakarta: Pustaka Pelajar.

Sugiyono. (2011). Metode Penelitian Kuantitatif, Kualitatif dan R\&D. Bandung: Afabeta.

Sudjana, Nana. (2009). Penilaian Hasil Proses Belajar Mengajar. Bandung: Remaja Rosdakarya.

Supardi. 2014. Kinerja Guru. Jakarta: PT Raja Grafindo Persada.

Supranto, J., Nandan, Limakrisna. (2007).

Perilaku Konsumen dan Strategi

Pemasaran: Untuk Memenangkan

Persaingan Bisnis. Jakarta: Mitra Wacana Media.

Suyati \& Suhari, Y. (2014). Pengaruh Kepemimpinan Transformasional dan Motivasi Kerja terhadap Kinerja Guru yang Dimoderasi oleh Iklim Sekolah Di MTs Sekecamatan Winong Kabupaten Pati. Jurnal Nasional ISSN Edisi Khusus No. 2 AgustusTahun 2014.

Timpe, D. (2011). Seri Manajemen Sumber Daya Manusia Kinerja, cetakan kelima, Jakarta : PT Elex Media Komputindo.

Wahjosumidjo. (2010). Kepemimpinan dan Motivasi. Jakarta: Ghalia Indonesia.

Yamin, M \& Maisah. (2010). Standarisasi Kinerja Guru. Jakarta: Persada Press. 